遮水シートを用いたため池堤体の地震後性能に関する考察门

中澤 博志* 澤田 豊** 小田 哲也*** 涉谷 啓**** 河端 俊典**

\title{
Post-Earthquake Performances of Small Earth Dams with Geosynthetic Clay Liners
}

by

\author{
Hiroshi NaKaZAwA*, Yutaka SAWAdA**, Tetsuya OdA***, \\ Satoru ShibuYa $* * * *$ and Toshinori Kawabata**
}

Recently, in addition to cohesive soils, geosynthetic clay liners (GCLs) are used for repair of small earth dams as a water barrier. In previous research, full-scale shaking table tests were carried out for four types of embankments under different installation conditions of GCLs in order to estimate their earthquake resistance. This paper firstly reviewed the previous studies and also have examined the deformation characteristics of embankments with GCLs based on 3D laser scanning. As a result, the deformation of the upstream side of embankments was greater than that of the downstream side in all cases. As for the post-earthquake performances, it is essential to avoid overflow after earthquake, and it has been suggested that GCLs should be set within width of crests as possible to retain the crest height at the downstream side.

\section{Key words:}

Small earth dam, Full-scale shaking table test, Geosynthetic clay liner, Seismic performance, Residual deformation, Earthquake resistance, Post-earthquake performance on water leakage

\section{1 緒言}

全国には約 19 万箇所の農業用ため池があり，約 7 割は 江戸時代以前に築造されたか築造年代が不明である. 特 に兵庫県では, 約 3.8 万箇所と全国一の数のため池を有し ており, 改修が必要なため池が多いのが現状である. 兵庫 県では通常，遮水方法として刃金土（はがねど）を用いた 前刃金工法により改修を行うが，当該工法の適用が困難 な場合に限り， ベントナイト系遮水シートを用いること がある.しかし, 遮水シート工法の耐震性は検証されてい ないのが現状であることから, 初期の検討として, 遮水シ 一ト工法を対象とした実大規模ため池堤体モデルによる

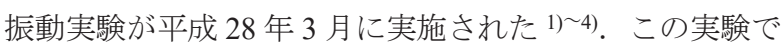
は，前刃金工法と遮水シートで改修された堤体の耐震性 およびの加振後性能が確認された. 加えて, 平成 30 年 1 月に実施した 2 回目の実験では, 遮水シートの敷設方法 と継ぎ目の影響に着目した実験を実施し, 地震後の遮水 シートの有効性を検証した ${ }^{5), 6 \text { ). }}$

本論文では, 上述の 2 回の実験で実施した計 4 ケース をまとめるとともに，特に 2 回目の実験での天端クラッ ク発生時の加速度応答ならびに加振前後の 3D レーザー スキャンにより得られた堤体の変形特性について, 既往
の実験結果と比較した. 最後に, 遮水シートで改修された ため池堤体の地震後の性能について考察を加えた.

\section{2 ため池堤体の地震被害事例}

本章では, 過去の大地震における主だったため池堤体 の被害について以下にまとめる.

1995 年 1 月の淡路島北部を震源とする最大震度 7 の兵 庫県南部地震において, 兵庫県内では約 1,400 箇所のため 池が被災した. Fig. 1 は, 前刃金工法の堤体 (兵庫県小野 市鶴池) における堤体頂部の縦断方向に長さ $12.5 \mathrm{~m}$, 横断 方向 2 箇所に開口幅 $1 \sim 6 \mathrm{~cm}$ のき裂が生じた事例である. このように, 他の堤体においても, クラックや沈下, 法面 の滑落等損傷が多数確認されたが, 地震発生が渇水年の 冬期で, 貯水位が低かったこと等により, 決壊による人命 への被害は発生しなかった ${ }^{7)}$. 一方, 2011 年 3 月の東北 地方太平洋沖地震では, 福島県の藤沼湖 (ため池) が地震 動で決壊し, 7 名死亡, 1 名行方不明という被害が発生し た. 2016 年 4 月の熊本地震では, 熊本県益城町で震度 7 の地震が連続で発生し, 甚大な被害に見舞われた. 地震当 時の資料として,「平成 28 年（2016 年）熊本地震の農林 水産業関係被害の状況」8)を確認すると, 熊本県内の点検 対象である 122 箇所のため池のうち, 109 箇所は異常が無

$\dagger \quad$ 原稿受理＼cjkstart令和元年6月9日Ｒeceived June 9, 2019 C2020 The Society of Materials Science, Japan

* 防災科学技術研究所 地震減災実験研究部門 †306-0006 つくば市天王台

Earthquake Disaster Mitigation Division, National Research Institute for Earth Science and Disaster Resilience, Ten-nodai, Tsukuba $306-0006$.

** 神戸大学大学院 農学研究科 $=657-8501$ 神戸市灘区六甲台

Graduate School of Agricultural Science, Kobe University, Nada-ku, Kobe 657-8501.

*** 兵庫県庁 $\bar{T} 650-8567$ 神戸市中央区下山手通

Hyogo prefecture, Chuo-ku, Kobe 650-8567.

***** 神戸大学大学院 工学研究科 $=657-8501$ 神戸市灘区六甲台町

Graduate School of Engineering, Kobe University, Nada-ku, Kobe 657-8501. 


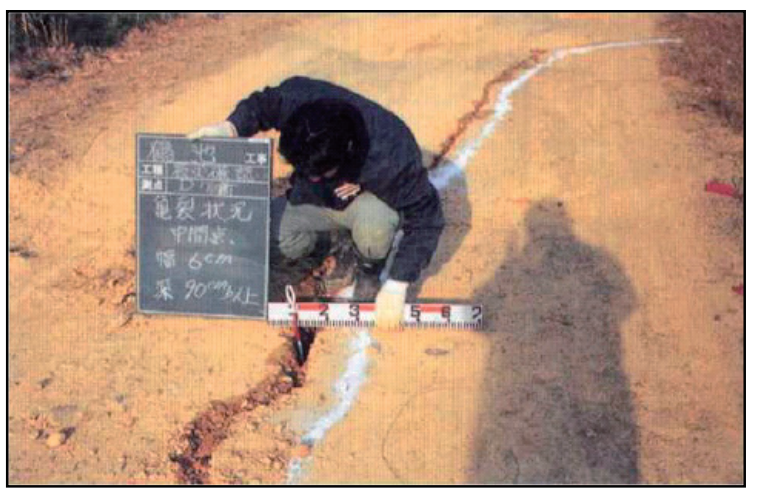

Fig.1 Damage situation of Tsuru-ike small earth dam.

く,クラック等の変状が確認されたのは, 大切畑ため池を 始めとする 13 箇所であったことが示されている.

一方, ため池堤体の被害事例に関する調査・研究につい

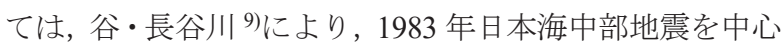
とする 5 つの地震被害についてまとめられており，ため 池堤体の地震時被害の傾向として, a)斜面滑り・はら夕だ しによる変状は，上流側が下流側に比べて倍程度発生し ている，b)基礎地盤や堤体土が砂質土の場合，被害率が高 い，およびc)地震時の貯水率 が高い場合に大きな被害に 結び付きやすいこと等が示されている.

上述の被苂事例や研究結果にも示寸通り，古くからの ため池は, 老朽化が進み, 漏水が多くなるなど決壊のリス クが高くなっているため，改修が急務となっているのが 現状である。

\section{3 遮水シートエ法の現状}

一般的なため池改修は前刃金工法が採用されているが， 現場条件等により前刃金工法の採用が困難な場合に限り, その代替として, Fig. 2 に示寸様に, 厚さ数 mm のベント ナイト層を織布等で挟んだベントナイト系シートを用い る遮水シート工法を採用する事例がある.なお，前刃金工 法の採用が困難な場合を例示すると，a)刃金土の運搬ルー トが無い場合，b)交通安全上の制約がある場合，およびc) 刃金土の購入場所が遠方で運搬費用が高い場合である。 遮水シート工法のメリットとしては, a)現場発生土を有効 利用でき，残土処分量（費）の増加（高騰）を抑制する，

b)土の搬入車両数の低減による, 特に住宅密集地を土砂運 搬する場合に家屋への過度な影響の回避，また，車両数減 少による環境負荷低減への期待，および c)土取場の土質 変化や土量の不足等のトラブルがなく，コア土の密度試 験や現場透水試験の時間短縮など，施工計画や工程管理 が容易となることが挙げられる.

耐震設計手法に関し，前刃金工法では，刃金土も地盤材 料であることから，通常の安定計算により堤体盛土の耐 震性を確認している。一方, 遮水シート工法については, シートの物理的・力学的評価方法が未確立であるために, シートを考慮せずに，安定計算を実施しているのが現状 である. 現行の耐震基準 ${ }^{10)}$ に対しては, 重要度に応じた 3

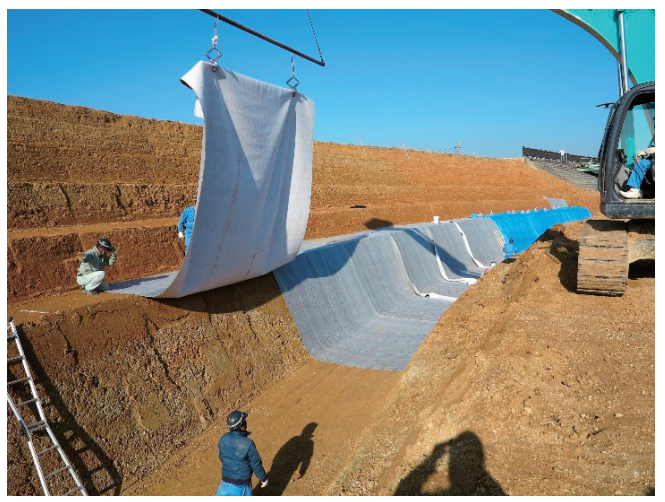

Fig.2 Situation of construction of Geosynthetic Clay Liner ${ }^{5)}$.

種類の堤体のランク付け (AA, A および B 種) があるが, $\mathrm{AA}$ 種のため池は，レベル 1 およびレベル 2 地震動による 検討を行い, $\mathrm{A}$ 種ではレベル 1 のみとなる. 現状として, レベル 1 地震動の検討では, 堤体の盛土材料の強度のみ で設計震度 0.15 を考慮した円弧すべり計算により安定性 を確認している. 一方, レベル 2 地震動に対する検討事例 が少ないのが現状であるため, 実大実験では, レベル 2 相 当に見立て正弦波を用いた加振実験を行い, 而震性や加 振後の堤体性能の評価を試みた。

\section{4 実大実験概要}

既に述べた通り，平成 28 年 3 月には，標準的な堤体 断面を用い, 前刃金工法 (Case1) および一枚の遮水シー トを階段状に敷設したケース (Case2), 続いて平成 30 年 1 月に実施した実験では，堤体法面に平行してシートを 直線状に敷設したケース（Case3），および階段状に敷設 し途中で継ぎ目を設けたケース（Case4）についての実大 実験を実施した。本論文では，既往の実験結果 ${ }^{1) ~ 6) に つ ~}$ いてまとめるとともに, これまで議論されていない Case3 と Case4 で発生した天端クラックと堤体法肩での 加速度の関係ならびに 3D レーザースキャンから得られ た堤体の変形状況について述べる.

\section{$4 \cdot 1$ 試験体概要}

Table 1 に全 4 ケースの概要と堤体断面を示寸. Case1 お よび Case2 は，H28 年 3 月に実施した前刃金工法および 一枚の遮水シートを階段状に敷設したモデルである。一 方, H30 年 1 月に実施した Case 3 および Case4 について は，階段状に敷設し途中で継ぎ目を設けたモデルおよび 堤体法面に平行してシートを直線上に敷設したモデルで あり, Case1〜4 のすべてのケースで同様な堤体形状とな っている. 堤体の基本諸元は堤高 $3 \mathrm{~m}$, 天端幅 $1.5 \mathrm{~m}$, 法面 勾配 $1: 1.5$ および基盤層 $0.2 \mathrm{~m}$ であり, 上流側には水位 $2.5 \mathrm{~m}$ の湛水部が設けられている. 本実験における堤体諸元の 設定にあたり，兵庫県内の小〜中規模のため池で最も数 が多い堤高 3〜 $5 \mathrm{~m}$ を対象としたことと, 土槽内で最大限 の堤体規模を構築することを優先し, 最終的に堤高を $3 \mathrm{~m}$ に設定した. 以下, Case3 およびCase4 について詳しく述 ベる。 
Table 1 Comparison of experimental cases.

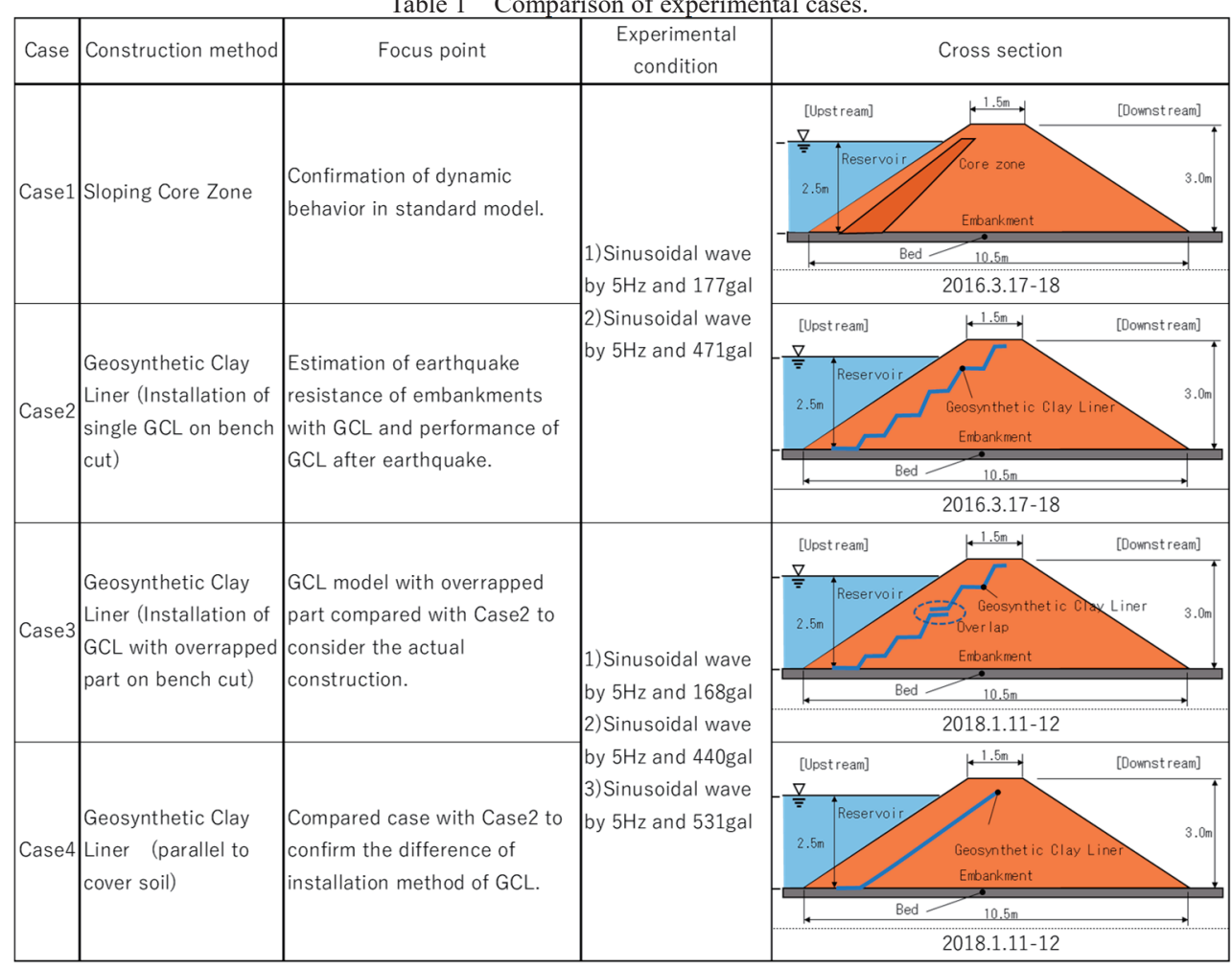

Case3 および Case4 で扱う実験モデルについては, 縮小 モデルを用いた数ケースの予備実験 ${ }^{11)}$ により決定した.

Table 1 に示す通り, Case2 および Case3 は階段状敷設であ り，Case4 は直線状敷設となっている. Case2 では，一枚 のシートで敷設されているのに対し, Case3では, 実験断 面（堤軸直角方向）上で 2 枚のシートが使用され，ラップ 部を伴う継ぎ目が設けられている。シートはロール状の 既製品であり，堤体のサイズに合わせて特注されないこ とがラップを設けた大きな理由の一つである.また，直線 状敷設である Case4 では, Case2 およびCase3 に比べ使用 するシートの延長が短くなるメリットがあるが，近年採 用された事例は少ない. なお, 実績のある階段状敷設は, 水平部分を設けることで転圧は容易となるが，盛土を階 段状に段切りする手間がかかること，また使用するシー トの総延長も長くなることがデメリットと言える．先行 実施された Case2 の結果から，堤体がシートを境にして 振動特性が異なることが確認されており 2), Case4 はシー トの敷設方法の違いによる影響を明らかにする目的も兼 ねられた。

\section{$4 \cdot 2$ 地盤材料および施工方法}

遮水シートに用いられたベントナイト遮水シートは, Case2〜4 で同じ仕様の製品を用いた．ため池堤体を主に 構成するランダム材料については, Case1, Case2 と Case3, Case4 で若干異なる. Fig. 3 に示す堤体材料の粒径加積曲 線では, Case1 および Case2 に比べ, Case3 および Case4 のランダム材料の砂分と碩分が多く含まれているが，後 述の実験結果から, Case2 と Case3 の堤体の変状が同等で あったことから,この材料の違いについては, 特に実験結

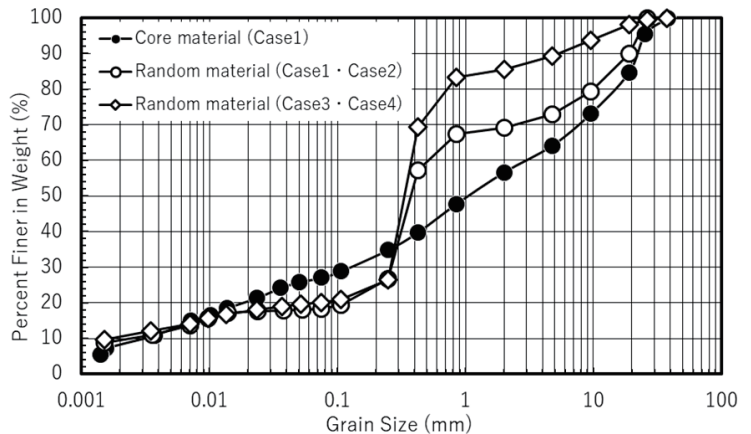

Fig.3 Grain size distribution curve $e^{4), 5)}$.

果や遮水シートの評価に影響はないものと考えられる. また, Table 2 に示す通り, ランダム材料の最大乾燥密度 $\rho_{\mathrm{d} m a x}$, 最適含水比 $w_{\mathrm{opt}}$ をはじめ, 両ランダム材料の物理特 性に大きな違いはない. なお, 堤体の施工方法, 堤体材料 の物性值および強度定数については参考文献 1)～6)に詳 述されているため, ここでは概要を示す.

Table 1 に示す寸べてのケースで，堤体の締固め度は $D_{\mathrm{c}}$ =96〜97\%程度として施工された. 1 回の実験で, 2 種類 のため池堤体を造成するため, Fig. 4 に示すように, 内寸 が長さ $L=12.59 \mathrm{~m}$, 高さ $H=3.55 \mathrm{~m}$ および幅 $W=2.50 \mathrm{~m}$ の 鋼製土槽 2 基を用いた。 写真に示す堤体右側は湛水部と なっており，この湛水部に造成後， $2.5 \mathrm{~m}$ の水深となるよ う注水した。

堤体の締固め度の決定に際し, 試験盛土を行い, 巻出し 厚および転圧回数等の施工要領を決定した。試験施工の 結果から, ハンドローラーによる締固め回数を 6 回, 仕上 げ層厚を $20 \mathrm{~cm}$ にするための巻出し厚は $23 \mathrm{~cm}$ として，土 
Table 2 Physical and Mechanical Properties of Embankment

\begin{tabular}{|c|c|c|c|c|c|}
\hline \multirow{2}{*}{\multicolumn{3}{|c|}{ Index }} & \multirow{3}{*}{$\begin{array}{c}\text { Case } 1 \\
\text { Core material } \\
2.648 \\
\end{array}$} & \multirow{2}{*}{\multicolumn{2}{|c|}{$\begin{array}{c}\text { Case } 1 \cdot \text { Case } 2 \text { Case } 3 \cdot \text { Case } 4 \\
\text { Random material } \\
\end{array}$}} \\
\hline & & & & & \\
\hline Density of soil particles & $\rho_{d}$ & $\mathrm{~g} / \mathrm{cm}^{3}$ & & 2.644 & 2.655 \\
\hline \multirow{4}{*}{ Soil type } & Gravel & $\%$ & 43.3 & 30.8 & 14.5 \\
\hline & Sand & $\%$ & 29.6 & 50.8 & 65.5 \\
\hline & Silt & $\%$ & 12.1 & 6.1 & 6.9 \\
\hline & Clay & $\%$ & 10.9 & 12.3 & 13.1 \\
\hline \multicolumn{3}{|c|}{$\begin{array}{lll}\text { Maximum particle diameter } \quad D_{m a} & \mathrm{~mm} \\
\end{array}$} & 38.1 & 26.5 & 37.5 \\
\hline \multicolumn{3}{|c|}{ Uniformity coefficient $U_{c}$} & 1000 & 184.8 & 195.0 \\
\hline \multicolumn{2}{|c|}{ Average particle diameter $D_{50}$} & $\mathrm{~mm}$ & 1.100 & 0.367 & 0.350 \\
\hline \multicolumn{2}{|c|}{ Maximum dry density $\rho_{d \max }$} & $\mathrm{g} / \mathrm{cm}^{3}$ & 1.824 & 1.890 & 1.906 \\
\hline \multicolumn{2}{|c|}{ Optimum water content $\quad w_{o p t}$} & $\%$ & 15.70 & 12.60 & 13.20 \\
\hline \multicolumn{2}{|l|}{ Plasticty Index $I_{p}$} & & 11.6 & NP & NP \\
\hline \multirow{2}{*}{$\begin{array}{l}\text { Triaxial compression test } \\
\text { (CUB) }\end{array}$} & $c^{\prime}$ & $\mathrm{kN} / \mathrm{m}^{2}$ & 9.6 & 0.0 & 8.9 \\
\hline & $\phi$ & $\circ$ & 32.5 & 37.2 & 32.8 \\
\hline
\end{tabular}

槽内の造成作業の目安とした. 各層の転圧後には, 締固め 密度, 含水比を測定し, 堤体造成完了後, 法面整形を行っ た. 遮水シート工法については, 堤体造成後, 段切りなら びにすき取りを行い, ベントナイトシートを敷設した. 敷 設後には, 再度ランダム材料を敷均し, 振動プレートコン パクタあるいはランマによる転圧を行い，堤体の仕上げ を行った. すべての施工完了後, 上流側に注水を開始した 震動実験に際しては, 水の飛散を防止するため, 湛水側の 一部をビニールシートで覆うとともに，水面に消波材を 設置した.

\section{$4 \cdot 3$ 加振実験およびその他の調查}

震動実験の実施にあたり，防災科学技術研究所所有の 実大 3 次元震動破壊実験施設（E-ディフェンス）を用いた。 震動台施設の仕様を Table 3 に示寸が，堤高 $3 \mathrm{~m}$ を有する 実大規模のため池堤体の地震時の破壊挙動を再現するに は充分な性能を有している.

加振による堤体の変状を確認するため, 加振実験前後 に光波測量，3D レーザーによる計測，およびサウンディ ングを実施し, 堤体の変状を調べた. 加振では Fig. 5 に示 寸様に，漸增・漸減部それぞれ 10 波を含む $5 \mathrm{~Hz}$ の正弦波 60 波を堤軸直角方向に入力した. 加振時には, 4 ケース寸 べてにおいて，堤体内に設置した加速度計，間隙水圧計， および天端と下流側法面に設置したレーザー変位計によ る計測を行っている.

加振条件は Table 1 に示した通り, Case1 および Case2 では, 2 回目の加振における振動台応答值で最大 $471 \mathrm{Gal}$, 一方, Case3 およびCase4 では, 2 回目の加振で 440Gal の 加振を行ったが，堤体に目立った損傷が見られなかった ことから，さらに加速度レベルを上げ，531Gal の加振を 行い, 天端に顕著なクラックを確認し実験を終了した.

\section{5 実験結果}

本章では，既往研究をレビュ一するとともに，Case3 お よび Case4 を中心に, 加振時生じた天端クラックと法肩 部の応答加速度の関係および加振後の残留変形について 述べることとする。

\section{$5 \cdot 1$ 既往実験のレビュー1) 6)}

$\mathrm{H} 28$ 年 3 月および $\mathrm{H} 30$ 年 1 月に実施したそれぞれの実 験は，すでに参考文献 1) 6)で報告されている. $\mathrm{H} 28$ 年 3

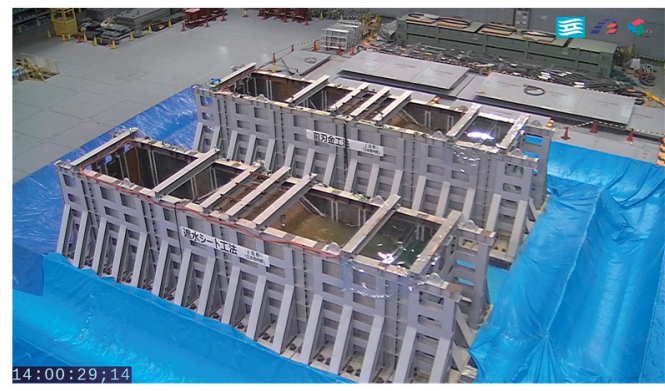

Fig.4 Soil container for full-scale shake table test.

Table 3 Specifications of Full-Scale Shake Table.

\begin{tabular}{|c|c|c|}
\hline Loading capacity & \multicolumn{2}{|c|}{$12 \mathrm{MN}(1,200$ tonf) } \\
\hline Table size & \multicolumn{2}{|c|}{$20 \mathrm{~m} \times 15 \mathrm{~m}$} \\
\hline Driving type & $\begin{array}{c}|c| \\
\text { control }\end{array}$ \\
\hline Shaking direction & Horizontal $(\mathrm{X}, \mathrm{Y})$ & Vertical (Z) \\
\hline Maximum acceleration & $900 \mathrm{~cm} / \mathrm{s}^{2}$ & $1500 \mathrm{~cm} / \mathrm{s}^{2}$ \\
\hline (at maxumum loading) & $200 \mathrm{~cm} / \mathrm{s}$ & $70 \mathrm{~cm} / \mathrm{s}$ \\
\hline Maximum velocity & $\pm 100 \mathrm{~cm}$ & $\pm 50 \mathrm{~cm}$ \\
\hline Maximum displacement & Overturning: & Yawing: \\
\hline \multirow{2}{*}{$\begin{array}{c}\text { Maxmum allowable } \\
\text { moment }\end{array}$} & $150 \mathrm{MN} \cdot \mathrm{m}$ & $40 \mathrm{MN} \cdot \mathrm{m}$ \\
\hline
\end{tabular}

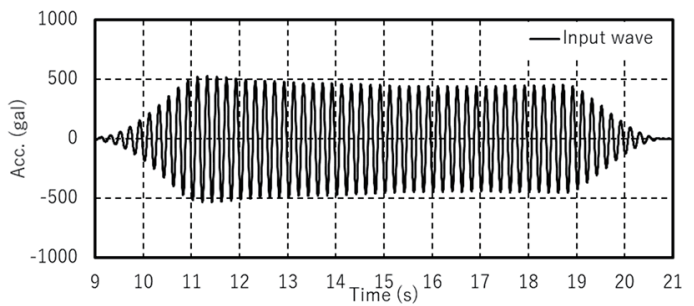

Fig.5 Input wave form (final test case by maximum acceleration of 531 Gal at $\mathrm{t}=11.425 \mathrm{~s})^{5}$.

月の実験を対象に, 澤田ら ${ }^{1)} は$ 本プロジェクトの計画を中 心とした報告をしている. また, 当該実験を対象に, 小田 $ら^{2)}$ は, Case2 の試験体における加振時動的挙動および加 振後のクラック調查, そして中澤ら ${ }^{3)}$ は, Case1 と Case2 の残留変形量の比較を行うため, 3D レーザー計測結果を まとめ報告している. Sawada et. al. $\left.{ }^{4}\right)$ は, Case1 と Case2 の 動的挙動の比較を通じ, 堤体の地震時安定性における上 流側の締固めの重要性について述べている. 一方, H30 年 1 月に実施した実験については, Sawada et. al. . $\left.^{5}\right)$ は, Case3 において加振後のシートの損傷調査を実施し，ランダム 材料に混入にされている硫のくいこみ食い込みが，シー 卜の遮水性に及ぼす影響について述べ，参考文献 6)では, 遮水シートが敷設された堤体の安定計算手法の提案を行 っている．上記で得られた Case1〜 4 における実験結果を 以下にまとめる.

標準的な堤体断面を用いた前刃金工法 (Case1)，および 遮水シート工法(Case2)により改修されたため池堤体の実 大模型加振実験を実施した結果, 最大 $471 \mathrm{Gal}$ の正弦波加 振後, Fig. 6 亿示寸通り, 遮水シ一ト工法による堤体天端 に比較的大きなクラックが発生したが, 漏水には至らず, 


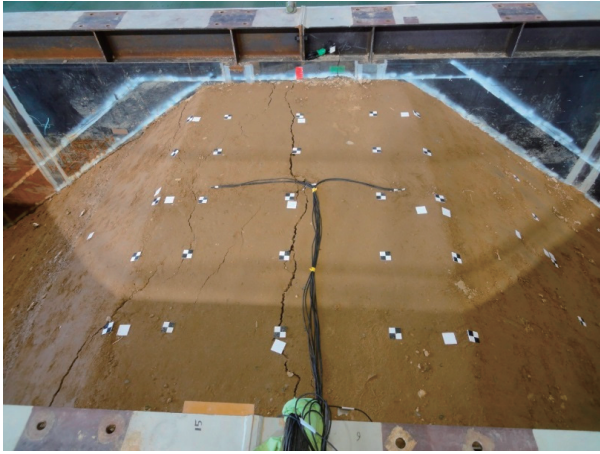

Fig.6 Cracks observed at the crest of the embankment retrofitted by Geosynthetic Clay Liner(Case 2$)^{1)}$.

前刃金工法とともに，堤体の要求性能を満足する結果が 得られた。遮水シート工法において堤体の動的応答特性 を詳しく調ベた結果，ベントナイトシートを境に上流側 堤体と下流側堤体が異なる挙動を示しており，シート上 流側の飽和土とシート下流側の不飽和土の振動特性の相 違，および土とシートの摩擦強度が土のせん断強度より も低いことが主要因として挙げられている.また, 加振で 生じた天端のクラックに対し，掘削調査によりその到達 深さが調べられている。水に溶いた石灰をクラックに流 し込み，石灰到達状況を確認した結果，鉛直方向に深さ $30 \mathrm{~cm}$ まで達した後，ベントナイトシートの表面前法側全 体的に付着し，ベントナイトシートと上流側盛土間で最 大 $1 \mathrm{~cm}$ の空隙が発生していることが確認された.

Case3 では, 階段状に設置された遮水シート中段部に重 ね合わせ部が設けられているが, 2 枚のシートに接着され た加速度計の応答および加振後掘削調査による目視確認 より，重ね合わせ部のずれは加振中も加振後も生じなか った。また，Case4では，遮水シートを直線状に配置した が, 加振によりシート上流側が大きく滑り落ち, 階段状配 置よりも耐震性が低いことが明らかとなっている。

\section{$5 \cdot 2$ 時刻歴データ（Case3 および Case4）}

Case3 および Case4 の 531Gal 加振時の堤体法肩部（Fig. 7）の加速度応答の時刻歴を Fig. 8 に示す.

(a)に示す Case3 の階段状敷設では， $t=16 \mathrm{~s}$ 付近までは, 上流・下流での加速度応答の傾向に差はほとんど認めら れないが, それ以降では, 上流側法肩部では上流方向 $(+)$ に，下流側法肩部では下流方向（一) に加速度応答が増大 している様子がわかる. 結果的に, 応答加速後の最大值は, 加振の後半において, 上流側で $1742 \mathrm{Gal}$, 下流側で-1717Gal を示した. 一方，直線状にシートを敷設した Case4 につい ては，概ね $t=13 \mathrm{~s}$ 付近までは Case 3 と同様，上流と下流方 向の加速度に有意な差は認められないが，その後，特に上 流側において，加速度応答が上流方向（+）に片振りとな る傾向が確認できる. 加速度の最大応答值については, Case3 のようにほぼ同時刻で生じてはいないが，上流側で 1838Gal，下流側で-1981Gal であった。

いずれのケースも, 加振後半において, 上流側と下流側 の加速度に差異が生じたが，撮影動画を確認したところ，

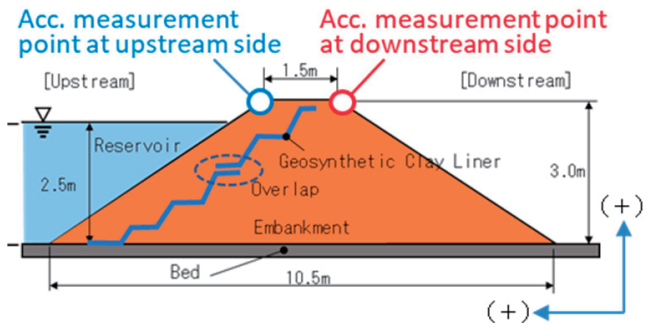

Fig.7 Measurement points of acceleration.

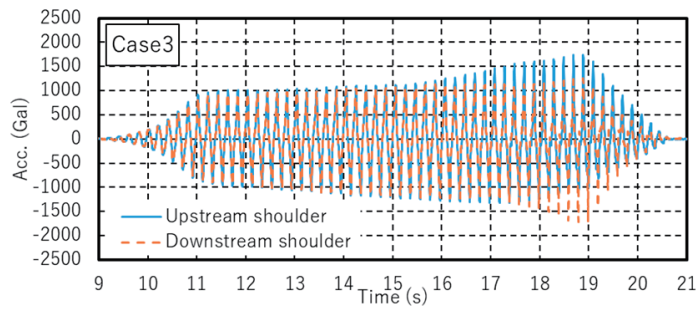

(a) Case 3

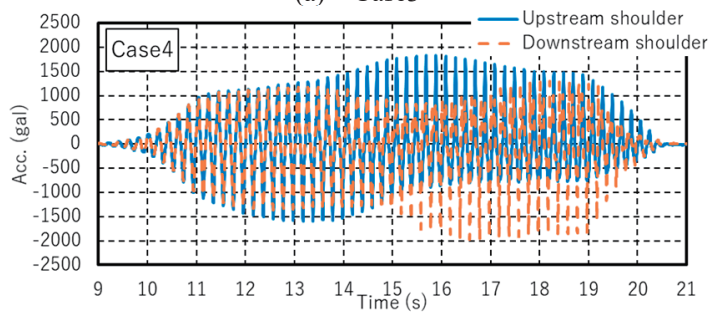

(b) Case 4

Fig. 8 Acceleration responses at the shoulder of embankment.

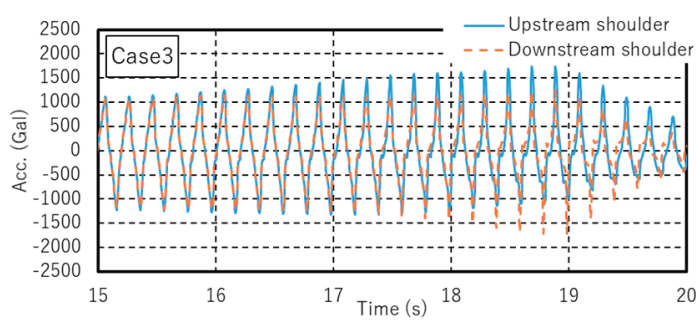

(a) Case 3

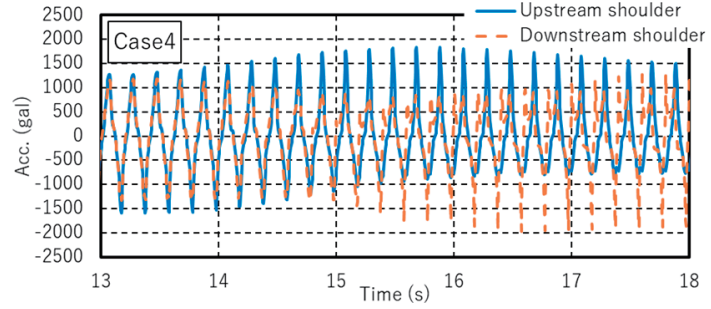

(b) Case 4

Fig. 9 Acceleration responses containing the time occurred cracks at the crests.

天端におけるクラックの発生時刻が Case 3 で概ね $t=17 \mathrm{~s}$ 付 近, Case 4 で $t=13 \mathrm{~s}$ 付近で発生していることが認められた. そこで, 上記時刻付近の応答加速度の時刻歴を Fig. 9 に示 す. Case2 において，シートを境に堤体の振動特性が異な ることが明らかになっているが 2), 同図で示すケースにつ いても, クラックが生じたタイミング以降に, 上流側と下 流側でそれぞれ加速度に差異が生じ，卓越する方向が異 なってくることから, クラックの発生は, 堤体の振動特性 と明らかに関係があると考えられる。また，Case4 を見る と，上流側と下流側で位相差が発生している。この傾向は, 

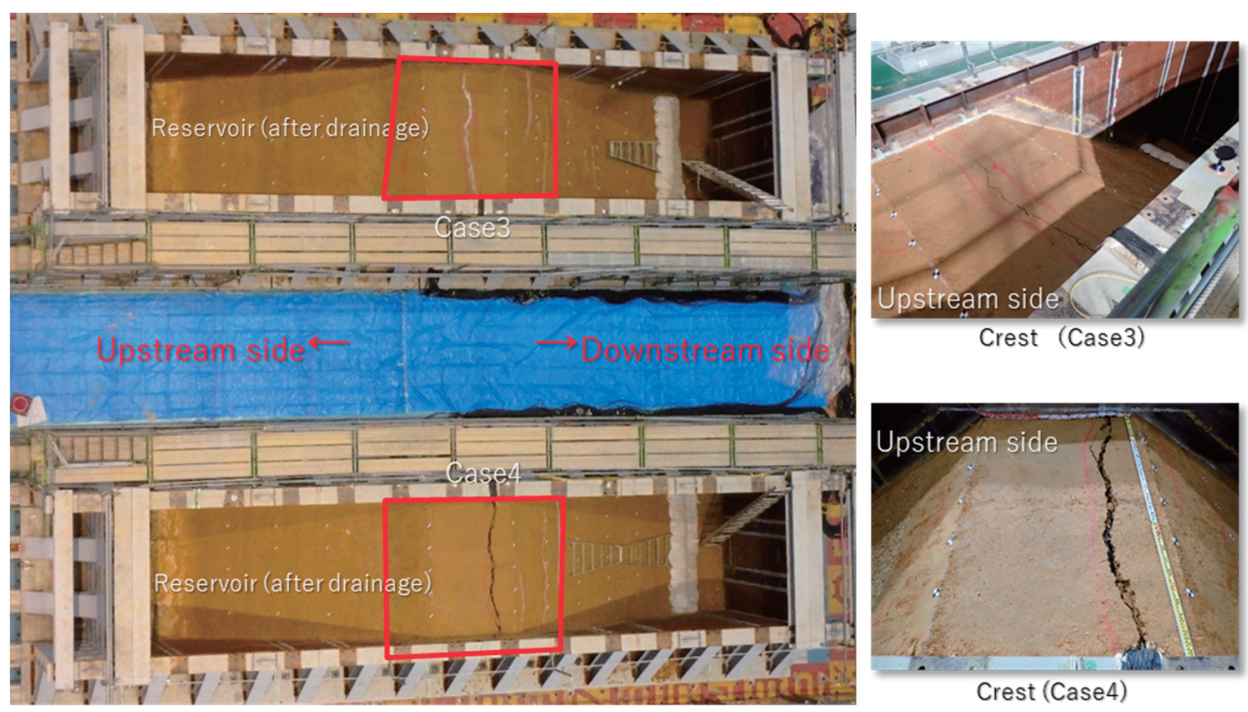

Crest (Case3)

Fig. 10 State of embankments after experiments and draining. Case 4 was inverted the original image ${ }^{6}$.

Case3 には顕著に見られないが, Fig. 10 で見て明らかな天 端クラックの発生程度の差と考えられる. 加振後の変状 については後述するが, Case4 に発生したクラックや段差 の程度が Case3 に比べ大きく，シートを隔てた上流側の 土塊が，上流側に大きく変形挙動を示した結果であると 推察される.

\section{$5 \cdot 3$ 残留変形}

堤体の変状を確認するため, 加振実験前後に 3D レーザ 一による堤体形状の計測を行った。 なお， Case1 および Case2 の残留変形に関しては文献 4)で詳しく述べられて いることから，ここでは割愛する. Fig. 11 に堤体上方から 見た加振後の点群データを示す. Case 3 およびCase4 共に, 下流側の法面である縦軸でおよそ 7100〜 11000mm の範囲 に対し，5000〜3000 $\mathrm{mm}$ の上流側の法面において，湛水時 に生じた表面の乱れが見られる. 次に, 加振後の変状の様 子を視覚的にわかりやすくするため, 加振前の堤体表面 を青色, 加振後は赤色に着色した加振前後の堤体の重ね 図を Fig.12に示す. 両ケースともに，加振後に堤体が全 体的に上流側に変形しかつ天端が沈下したことから，同 図において，天端を主体に加振前の青色着色部が現れて いる. 一方, 法面の下部の大半は, 加振後のはらみ出しを 示寸赤色着色部が確認出来る. この変形傾向は, Case3 に 比べCase4 で顕著である様子がわかる.

堤体全体の変状傾向を定量的に把握するため, Fig. 11 中 に示寸断面 2 に相当する堤体軸直交方向のセンターライ ンにおける加振前後の $3 \mathrm{D}$ レーザー計測と別途実施され た光波測量結果をまとめ Fig. 13 に示す. なお，加振後の 変形量は 10 倍に引き延ばしている. Fig. 13 より, 連続的

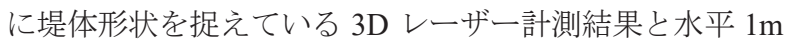
ピッチで法面に据えた光波測量結果はほぼ整合している ことがわかる. 両ケースともに, 天端が大きく沈下し，堤 体上流側で中腹から底部にかけてのはらみ出しが見られ， 上流側に変状をしている傾向がわかる.この傾向は, Case1 およびCase2 の結果と同様であり ${ }^{4)}$, 上流側の貯水が堤体

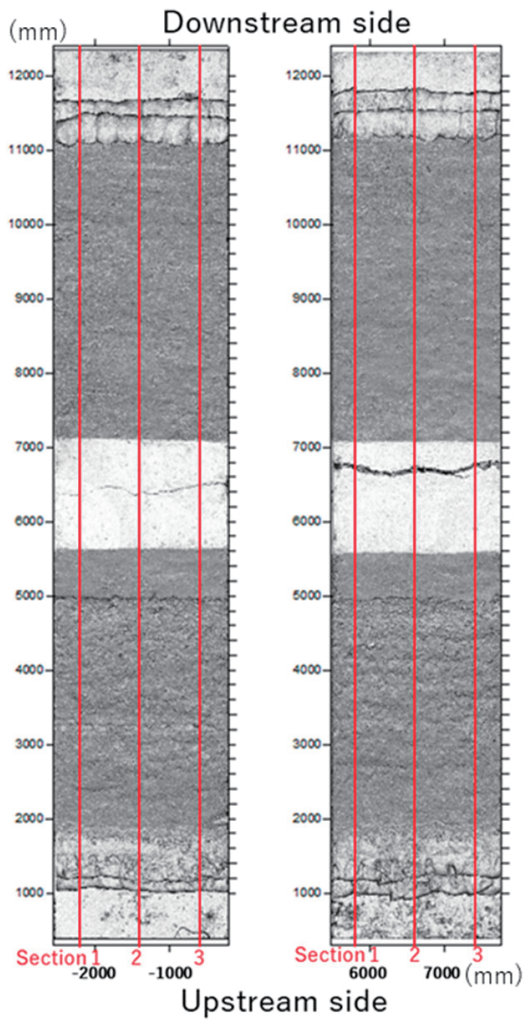

(a) Case 3

(b) Case 4

Fig. 11 Point cloud data by 3D territorial laser measurement.

の変形に影響を及ぼしていると考えられる．また，Case4 については天端に大きなクラックとそれに伴う段差が見 れ，より変状が著しいことがわかる.

Fig. 14 に加振前後の堤体高さの差分の分布を示す. な お, 図中には, Fig. 11 に示した断面 1～3 に沿った変形形 状を示している．断面ごとの相違はほとんど見られない が, Case3 の天端で約 $2 \mathrm{~cm}$, 一方, Case4 ではクラックを 除き天端の沈下は $5 \mathrm{~cm}$ 程度となった。 堤体天端の残留変 形傾向の違いについて, Fig. 15 にCase1〜4 における変形 分布を示す. 前刃金工法である Case1, 遮水シート工法に おけるシートの階段状敷設である Case 2 および Case 3 は, 


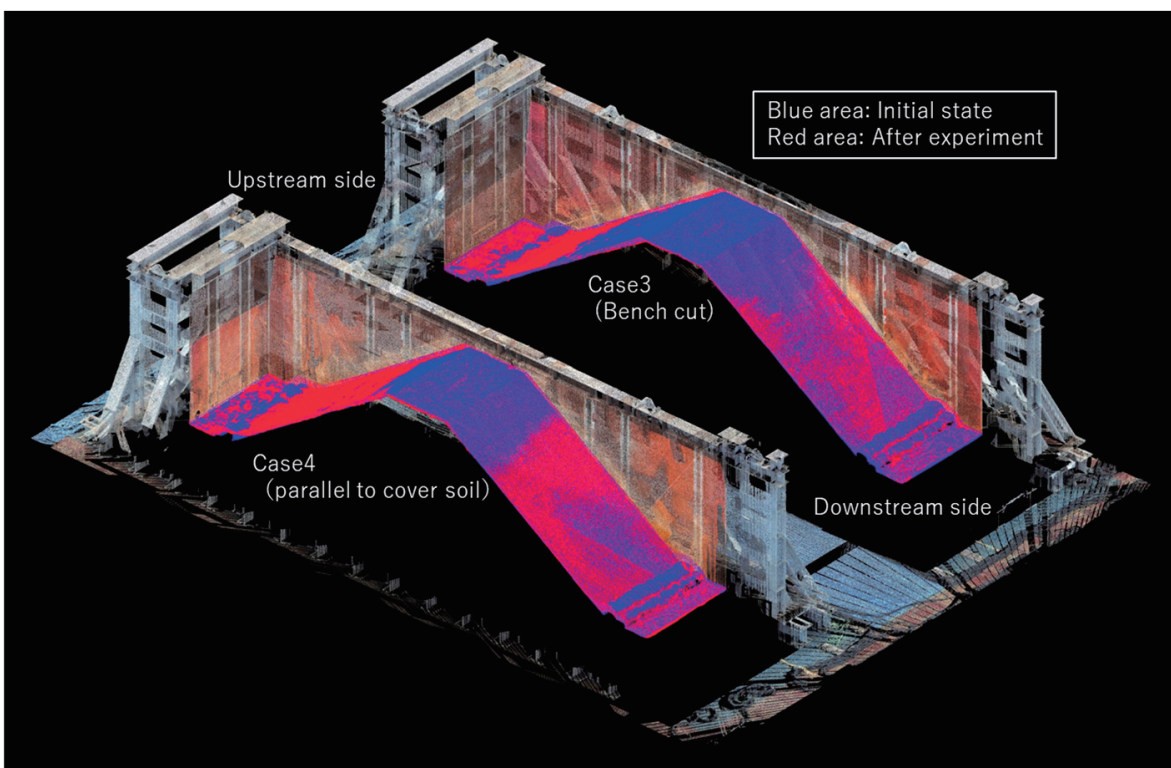

Fig. 12 Stacked figure of embankments before and after experiments.

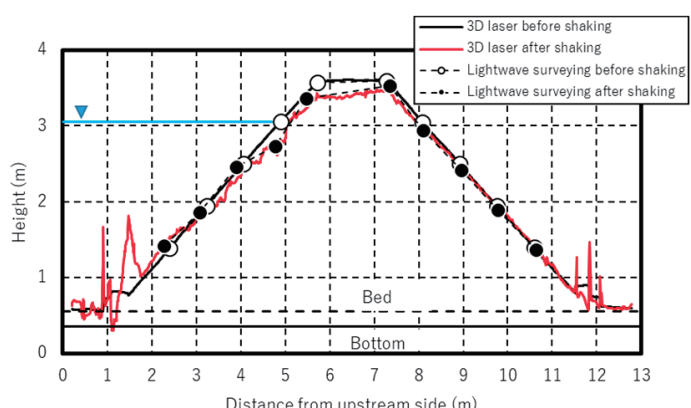

(a) Case 3

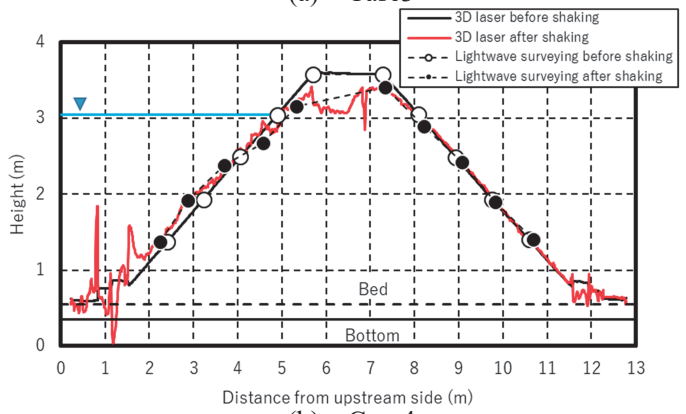

(b) Case 4

Fig. 13 Embankments form. The amount of deformations after experiments was increased 10 times.

クラックの有無があるものの，残留変形傾向が同様であ る。一方, Case4 の変状傾向は明らかに異なり，シートを 境界に段差が生じている.この傾向の違いは, Fig. 14 にお いて, Case3 に比べCase4 の上流側法面の隆起範囲が広く, シートの敷設方法の違いにより堤体の破壊性状が異なる ことによるものであり,これは既往研究 6で述べられてい る通り，シートを直線に敷設するよりも階段状に敷設す る方が堤体の安定性は高いことを示している. なお, す心゙ ての加振終了後，1 日間湛水状態で静置したが，上流側湛 水部の水位に变化は無く破局的な破壊に至る兆候が見ら れなかったこと，加えて下流側において堤体からの漏水 は見らなかったことから，本実験の地震後におけるシー

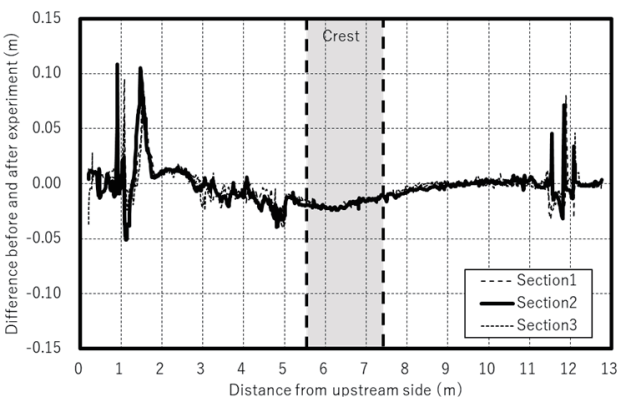

(a) Case 3

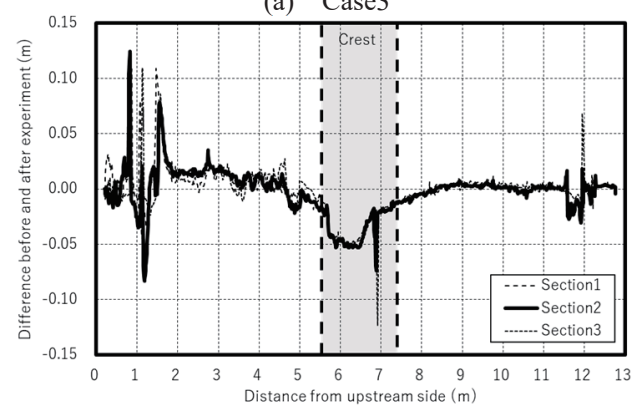

(b) Case 4

Fig. 14 Difference of the height of embankments before and after experiments. The 10 times amount of deformations after experiments was showed.

トの遮水性能は維持されていた可能性が非常に高いと言 える.

地震後における堤体そのものの性能を考えると，地震 により天端が大きく沈下あるいは破壊した場合，越流の 可能性が危惧されるため，地震後の損傷の有無に拘わら ず, 堤体の天端高の維持が必要となる.このような観点で Fig. 15 を確認すると, 総じて, 天端上流側における沈下が 大きく，下流側での沈下が小さいことがわかる. 特にシー 卜を敷設した 3 ケースを比較すると, Case4 において, 天 端に生じたクラックを境に，上流側と下流側でその傾向 が顕著に表れ，上流側の変状が著しいが，Case2４ にお 


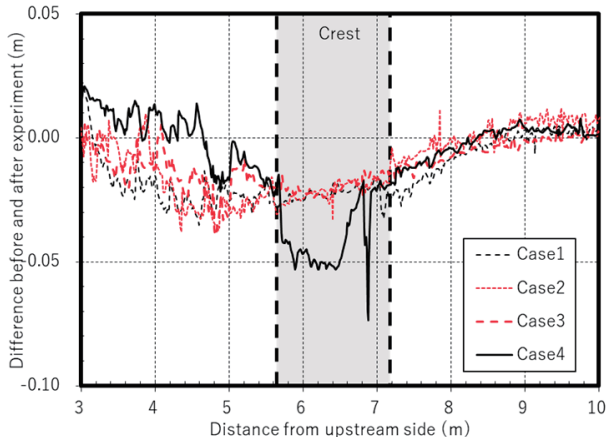

Fig. 15 Difference of the height of embankments height before and after experiments in all cases. The 10 times amount of deformations after experiments was showed.

ける下流側の法肩（7.2m 付近）の沈下量については，そ れぞれ $17.5,14.7$ および $20.9 \mathrm{~mm}$ を示しており，上流側の 損傷レベルに拘わらず，いずれのケースも越流に至る可 能性は低いレベルと判断できる．シート最上部の折れ曲 がり部直上にクラックが入るとともに，シートに沿った 上流側土塊の滑りが明らかとなっていることから，この 折れ曲がり部を天端幅の内側に設定し, 天端下流側高さ を維持することが, 設計上肝要と言えよう.

\section{6 結 言}

本論文では，遮水シートを設置したため池堤体の耐震 性を検証する目的で行われた実大規模加振実験の結果, 特に堤体の変形特性に着目して検討を行ったところ，地 震後性能について以下の知見を得た.

計 4 ケースの実験から, 堤体の変形傾向について, いず れのケースも下流側より上流側のほうが大きいこと，い ずれも決壊・漏水が発生しなかったことからシートの遮 水性能を満足することが明らかとなった。ささらに, シート の敷設方法に関しては，階段状の方が直線状敷設より堤 体の安定性が高いことが，加振前後の堤体高さの差分か ら, 再確認された. 地震後の越流対策として, 遮水シート 下流側の沈下を抑えるため, シート上部の折れ曲がり部 を天端幅の内側に設けることが重要であることが示され た.

今後, 遮水シート工法を導入する際の設計・施工のこれ らの結果を活かすことで，良質な刃金土が入手困難にな ってきた現状に対するため池改修工法の選択幅の広がり に繋がるものと思われる.

なお, 本研究は, 防災科学技術研究所と兵庫県の共同研 究および兵庫県・神戸大学の協力型共同研究の下に実施 された，研究計画策定や実験実施にあたり，E－ディフェ ンスを活用した減災対策推進委員会 (岡田恒男委員長) の 助言を受けた.また，実験に向けての具体的な段取り，実 施からデータ整理に至るまで，元神戸大学大学院農学研 究科（現国土交通省北海道開発局）の重元燷太郎氏，実験 当時兵庫県防災企画課（現在，南あわじ市に出向）の古林 智宏氏，および兵庫県農政環境部の谷本幹夫主査を始め
とする多くの方々のご助力を得た。関係者各位に謝意を 表します。

\section{参 考 文 献}

1) Y. Sawada, H. Nakazawa, S. Kataoka, S. Kobayashi, T. Oda, T. Kobayashi, S. Shibuya, T. Yamashita, K. Tani, K. Kajiwara, and T. Kawabata, "Full-scale shaking table tests for small earth dams with sloping core zone and geosynthetic clay lines" Geosynthetics Engineering Journal, Vol.31, pp.167-174 (2016).

2) T. Oda, Y. Sawada, H. Nakazawa, S. Kobayashi, S. Shibuya, and T. Kawabata, "Influence of geosynthetics clay liner laid in a staircase shape in embankment on seismic behavior of small earth dam", Geosynthetics Engineering Journal, Vol.31, pp.175-182 (2016).

3) H. Nakazawa, Y. Sawada, T. Oda, T. Kobayashi, S. Kobayashi, T. Kawabata, S. Shibuya, S. Kataoka and T. Yamashita, "Characteristics on residual deformation of small earth dams in full-scale shaking table tests", Journal of Japan Society of Civil Engineers (A1), Vol.73, No.4, pp.I_815-826 (2017).

4) Y. Sawada, H. Nakazawa, T. Oda, S. Kobayshi, S. Shibuya and T. Kawabata, "Seismic performance of small earth dams with sloping core zone and geosynthetic clay liners by full-scale shaking table tests", Soils and Foundations, Vol.58, No.3, pp.519-533 (2018).

5) Y. Sawada, H. Nakazawa, W.A. Take and T. Kawabata, "Full scale investigation of GCL damage mechanisms in small earth dam retrofit applications under earthquake loading", Geotextiles and Geomembranes, 10.1016/j.geotexmem.2019.03.001 (2019). (online published)

6) Y. Sawada, H. Nakazawa, W.A. Take and T. Kawabata, "Effect of installation geometry on dynamic stability of small earth dams retrofitted with a geosynthetic clay liner", Soils and Foundations. (submitted)

7) Division of food, agriculture, forestry and fisheries, Hyogo prefecture, "Journal of records on Farmland Facility damaged by the 1995 Hyogo-ken Nanbu Earthquake, on Jan. 17, 1996”, p.11 (1996).

8) Situation of agriculture, forestry and fisheries industries damaged by the 2016 Kumamoto earthquake, http://www.maff.go.jp/j/saigai/zisin/160414/kumamoto/ taiou.html (on Aug. 9, 2016)

9) S. Tani and T. Hasegawa, "Earthquake damage on earth dam by The 1983 Nipponkai-Chubu Earthqua ke”, Journal of Japanese Society of Agriculture Eng ineering, No.55, Vol.10, pp.17-25(1987).

10) "Small earth dam, Design guideline of land improvement project", Ed. Ministry of Agriculture, Forestry and Fisheries (2015) JSIDRE Press.

11) R. Shigemoto, R. Maki, Y. Sawada, N. Kotake, M. Suzuki, K. Shimizu, K. Inoue, K. Kaminobu, H. Nakazawa, T. Oda and T. Kawabata, "Small scale shaking tests on dynamic behavior of small earth dams with geosynthetic clay liners", Proceedings of the 2017 Annual Meeting of JSIDRE, pp.580-581 (2017). 